\title{
Natural remedies effective on stomachache in traditional medicine
}

\author{
Hori Ghaneialvar ${ }^{1}$, Naser Abbasi $^{1 *}$, Somayeh Shahsavari ${ }^{1}$ \\ ${ }^{1}$ Biotechnology And Medicinal Plants Research Center, Ilam University of Medical Sciences, Ilam Iran
}

\author{
*Correspondence to: \\ Dr. Naser Abbasi \\ ilamfarma@gmail.com
}

Received: 16 March 2020

Accepted: 02 April 2020

ePublished: 16 June 2020

Keywords: Pain, Medicinal plants, Gastrointestinal disorders, Persian medicine

\section{Citation:}

Ghaneialvar $\mathrm{H}$, Abbasi N, Shahsavari S. Natural remedies effective on stomachache in traditional medicine. Plant Biotechnology Persa. 2020; 2(1): 42-47.

Abstract
Stomach ache is one of the most chronic and debilitating abdominal pains. Medicinal
plants are one of the most accessible sources for treating diseases like gastrointestinal
disorders. In this review, we investigate and report the most important medicinal plants
recommended by Persian medicine for treating stomach aches and comparing them with
their proven effects in modern medicine. Gastric pain was probed in Persian medicine
reliable textbooks such as Cannon of Medicine (Ibn Sina), Tibbe-Akbari (Muhammad Ak-
bar Arzaani ), The Complete Art of Medicine (Kitab Kamil as-Sinaa at-tibbiyya) (Haly
Abbas), Explanation of insults and signs (Kermani) Tohfeh Al-Mo'menin (Seyed Moham-
mad Momen Tonekaboni), and some notes were taken. The results showed that Panicum
miliaceum, Punica granatum, Solanum nigrum, Calicotome spinosa, Tamarindus indica,
Cuminum cyminum, Prunus domestica, Matricaria recutita, Viola odorata, Plantago psylli-
um, Berberis vulgaris, Pyrus communis, Linum usitatissimum, Vitis vinifera were the most
important plant sources used in treating the stomach ache according to Persian medicine.
The findings of this study showed that the useful effects of many recommended plants in
Persian medicine are confirmed by recent scientific researches and are reliable.

\section{Introduction}

Stomach ache is one of the most important pains that all people have experienced during their lives at least once. It is one of the most chronic and debilitating abdominal pains $[1,2]$. In many cases, the cause of stomach ache is unclear. But, a wide range of factors can cause pain in the abdomen. These causes include Helicobacter pylori, maldigestion, irritable bowel syndrome, gastric reflux, gastric ulcer, etc. $[3,4]$. The reason for stomach pain can be anxiety, stress, delay eating in hunger and prolonged starvation [5,6]. There are other reasons for stomach ache including increased gastric acidity, food poisoning, food allergy, stress-induced nerve pain, stomach infections, menstruation, and even myocardial infarction [7]. Today, the use of medicinal plants is increasing rapidly. By using medicinal plants, complications of using chemical drugs can be prevented [8-12]. Stomach ache is often accompanied by certain symptoms including fever, vomiting, loss of appetite, inability to eat, and cramps. [13-18]. Recent documents showed that gastrointestinal problems such as stomach aches or stomach upset can be treated with medicinal plants [7]. Knowing the attitude of the ancient Persian medicine scholars in treating stomach aches by medicinal plants can be a good guide for planners and policymakers of the pharmaceutical industry in the world. Therefore, in this review, we investigate the most important medicinal plants affecting stomach ache in Persian medicine and comparing them with their proven effects in modern medicine.

\section{Methodology}

Gastric pain was probed in Persian medicine reliable textbooks such as Cannon of Medicine (Ibn Sina), Tibbe-Akbari (Muhammad Akbar Arzaani ), The Complete Art of Medicine (Kitāb Kāmil as-Sināa at-tibbiyya) (Haly Abbas), Explanation of insults and signs (Kermani) Tohfeh Al-Mo'menin (Seyed Mohammad Momen Tonekaboni), and some notes were taken.

\section{Results}

The results of the review of Persian medicine showed that the medicinal plants Panicum miliaceum, Punica granatum, Solanum nigrum,

Copyright (C) 2020 The Author(s). This is an open-access article distributed under the terms of the Creative Commons Attribution License (http://creativecommons.org/licenses/by/4.0), which permits unrestricted use, distribution, and reproduction in any medium, provided the original work is properly cited. 
Calicotome spinosa, Tamarindus indica, Cuminum cyminum, Prunus domestica, Matricaria recutita, Viola odorata, Plantago psyllium, Berberis vulgaris, Pyrus communis, Linum usitatissimum, Vitis vinifera and a number of other medicinal plants were the most important plant source used in treating the stomach ache according to Persian medicine. A complete list of medicinal plants and complementary information is presented in Table 1.

Table 1. Medicinal plants effective on stomach ache in traditional medicine

\begin{tabular}{llll}
\hline $\begin{array}{l}\text { Scientific } \\
\text { name } \\
\text { (Herbal) }\end{array}$ & $\begin{array}{l}\text { Herbal } \\
\text { family }\end{array}$ & $\begin{array}{l}\text { Domestic } \\
\text { name }\end{array}$ & Figure \\
\hline
\end{tabular}

Panicum miliaceum Poaceae Arzan

$\begin{array}{ll}\begin{array}{l}\text { Punica } \\ \text { granatum }\end{array} & \begin{array}{l}\text { Lythra- } \\ \text { ceae }\end{array}\end{array}$ $\begin{array}{lll}\begin{array}{l}\text { Solanum } \\ \text { nigrum }\end{array} & \begin{array}{l}\text { Solana- } \\ \text { ceae }\end{array} & \text { Tajrizi }\end{array}$

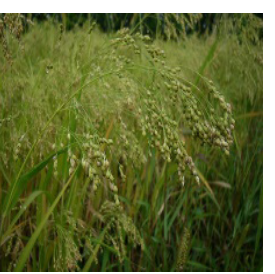

\begin{tabular}{|c|c|}
\hline $\begin{array}{l}\text { Calico- } \\
\text { tome } \\
\text { spinosa }\end{array}$ & $\begin{array}{l}\text { Fabace- } \\
\text { ae }\end{array}$ \\
\hline
\end{tabular}

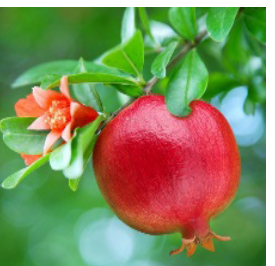

Viola odorata Violaceae

Banafsheh

Matricaria Asterarecutita ceae

Babouneh

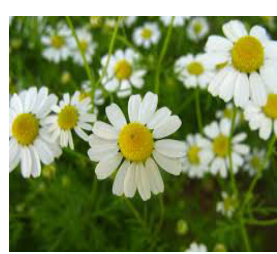

Plantago Plantagpsyllium inaceae

Esfarzeh

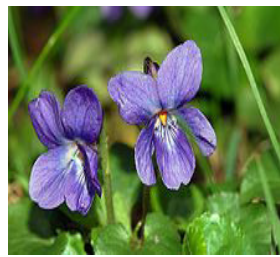

$\begin{array}{lll}\text { Berberis } & \text { Berberi- } & \text { Zereshk } \\ \text { vulgaris } & \text { daceae } & \end{array}$
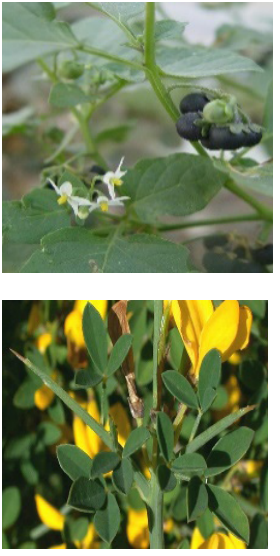

Pyrus Rosace-

communis ae

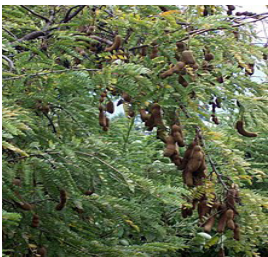

Linum

usitatissi- Linaceae Katan mum

Vitis vinifera
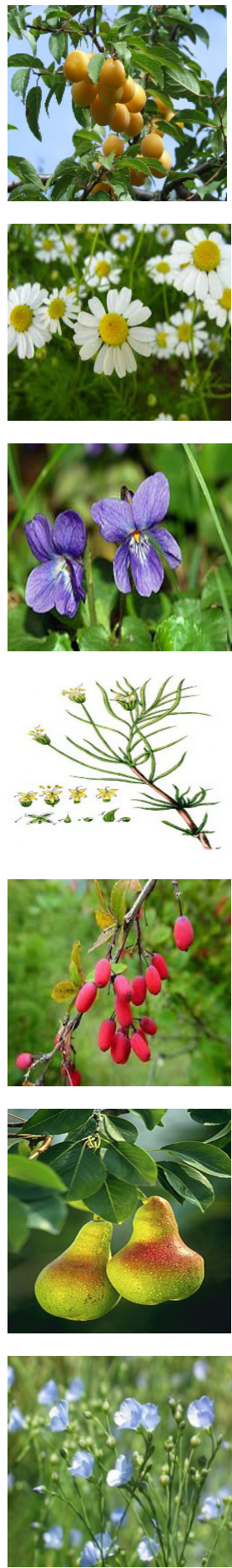

Cuminum Apiacecyminum ae

Zireh

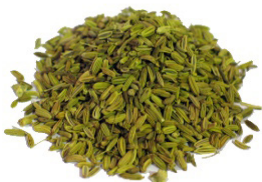

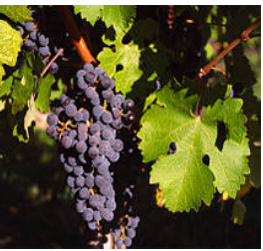




\begin{tabular}{llll}
\hline $\begin{array}{l}\text { Scientific } \\
\text { name } \\
\text { (Herbal) }\end{array}$ & $\begin{array}{l}\text { Herbal } \\
\text { family }\end{array}$ & $\begin{array}{l}\text { Domestic } \\
\text { name }\end{array}$ & Figure \\
\hline
\end{tabular}

$\begin{array}{ll}\text { Laurus } & \text { Laurace- Hobolqar } \\ \text { nobilis } & \text { ae }\end{array}$

nobilis ae Hobolqar

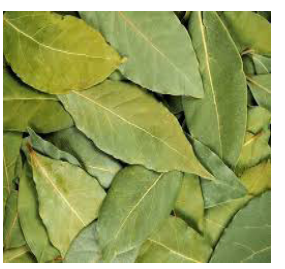

Pimpinella Apiaceanisum ae

Anison

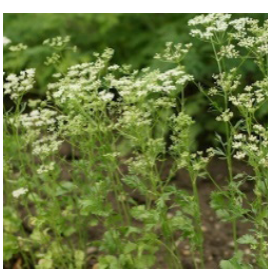

Hyoscy- Solana- Bazrolamus niger ceae banj

Cinnamomum zeylanicum

Lauraceae

Darchin

$\begin{array}{ll}\text { Cucurbita } & \text { Cucurbi- Kadou } \\ \text { pepo } & \text { taceae }\end{array}$

$\begin{array}{lll}\begin{array}{l}\text { Corian- } \\ \text { drum }\end{array} & \text { Apiace- } & \text { Geshniz } \\ \text { sativum } & \text { ae }\end{array}$
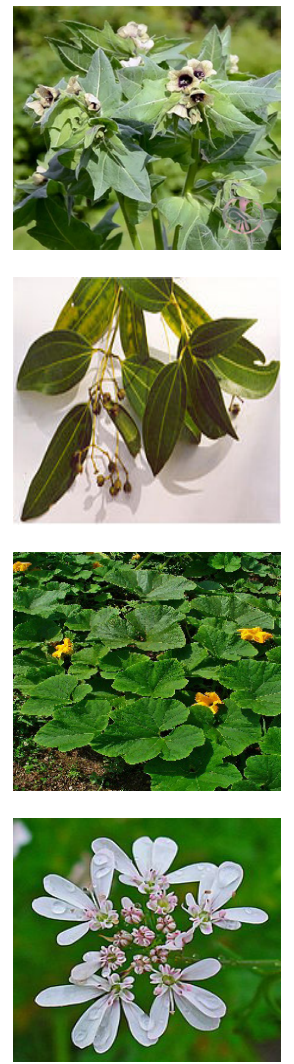

Aristolo- Aristolo- Zaravand chia longa chiaceae tavil

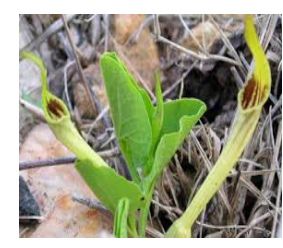

$\begin{array}{ll}\text { Mentha } & \text { Lamia- Naena } \\ \text { piperata } & \text { ceae }\end{array}$ Nat

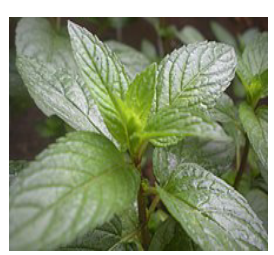

$\begin{array}{ll}\text { Elettaria } & \text { Zingiber- Hel } \\ \text { cardamo- } & \text { aceae } \\ \text { mum } & \end{array}$

$\begin{array}{ll}\begin{array}{l}\text { Rheum } \\ \text { ribes }\end{array} & \begin{array}{l}\text { Polygo- } \\ \text { naceae }\end{array}\end{array}$

Zingiber

Zingiber-

Zanjabil

Citrus

bergamia

\begin{tabular}{llll}
\hline $\begin{array}{l}\text { Scientific } \\
\text { name } \\
\text { (Herbal) }\end{array}$ & $\begin{array}{l}\text { Herbal } \\
\text { family }\end{array}$ & $\begin{array}{l}\text { Domestic } \\
\text { name }\end{array}$ & Figure \\
\hline
\end{tabular}
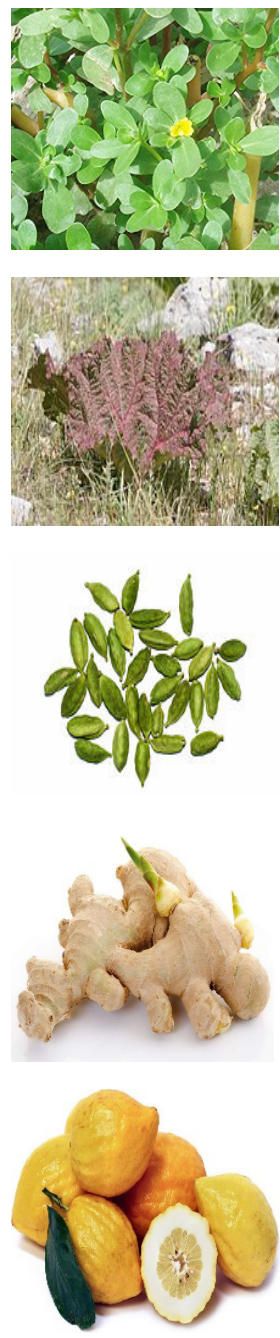

\section{Discussion}

Traditional medicine in the world has been used through the majority of the world population since ancient times [26,27]. The World Health Organization (WHO) has suggested that more than $80 \%$ of people in developing countries, particularly in rural and remote areas are using traditional medicinal, especially medicinal plants for their primary health care [28]. Considerable economic benefits seem to be the main reason in the use of medicinal plants and indigenous medicine for treatment and prevention of diseases. Poverty, communication difficulties and the unavailability of sophisticated modern health facilities are the most important reasons to force people to use traditional medicines for their diseases. The knowledge for uses medicinal plants against various diseases seems to be accumulated in areas where the consumption of herbal medicines is still important and continued, greatly [29-32]. An important issue in the use of medicinal plants is that a plant is usually used for several diseases [3336]. For example, Azadirachta indica other than stomachache is also used against skin diseases, smallpox, rheumatism, etc.

Medicinal plants reduce stomach ache by various mechanisms including antibacterial, anti-inflammatory, analgesic, anticholinergic and antioxidant effects. The points that have been considered in Persian medicine about stomach aches seem to have been 
completed from one period to another, and this knowledge has passed through the natural course of its transformation, which includes promotion and revision of the knowledge about herbal medicine. Taking this theory into account, it is necessary to carry out more experimental clinical studies to examine the authentic texts on Persian medicine in order to provide this knowledge to modern science and clinical pharmacology.

Two common reasons for stomach ache are inflammatory diseases and infections. Therefore, other than the plants presented here, any plant with antimicrobial [37-40] or anti-inflammatory activity [41-45] may have beneficial effects in stomachache. Stomach disorders like other pain associated disorders are related to oxidative stress [46]. Pomegranate extract (Punica granatum L.) reduces central and peripheral activity to relieve pain. Pomegranate extract protects from gastric injury and gastric lesions induced by indomethacin and ethanol respectively, the results confirm the benefits of pomegranate polyphenolics in the cure of pain and anti-inflammatory properties [47]. Chamomile (Matricaria chamomilla L., Asteraceae) is a herbal plant used as a remedy for pain and gastric disorders [48]. The results of a study indicated antiulcerogenic activity of $20 \%$ and $40 \%$ aqueous extracts of Laurus nobilis seeds and also in the oils of the seeds [49]. The fiber of psyllium decreases the number of abdominal pain episodes with IBS (in children) [50]. Results a study indicated fixed oil of L. usitatissimum (flaxseed/linseed) inhibited Inflammation induced by PGE2-, leukotriene-, histamine- and bradykinin, this oil also inhibited induced inflammation by arachidonic acid [51]. Peppermint reduces abdominal pain [52]. Hyoscyamus niger seeds have anti-inflammatory and analgesic effects [53]. The results of one study showed that Portulaca varieties also have some of the traditional uses claimed of wild species to relieve inflammation and pain [54]. The aqueous and ethanolic extracts of C. sativumseeds it had a good effect on analgesic and anti-inflammatory activities [55]. Extract of rhizome Zingiber officinale was examined for its analgesic and anti-inflammatory properties in albino rats, the results of this study showed that this extract had analgesic and anti-inflammatory properties [56]. The results of a study showed that Solanum nigrum berries may exert a protective effect on the stomach by a free radical scavenging action [57]. Tamarindus indica L. aqueous fruit extract inhibited the writhing test and hot plate test in a dose-dependent manner [58]. Therefore, medicinal plants that have antioxidant activities may be useful in these patients. If it is through, these plants which have antioxidant activities may have done their effects, in part through this mechanism. Furthermore, other plants with antioxidant activity [59-61] might be beneficial in this group of patients.

\section{Acknowledgments}

The authors would like to thank the Vice-chancellor for the Research and Technology Deputy of the Ilam University of Medical Sciences and Biotechnology and Medicinal Plants Research Center for funding this study.

\section{Authors' contributions}

$\mathrm{HGH}$ and NA searched and reviewed the literature and $\mathrm{HGH}$ and SSH prepared the first draft of manuscript; $\mathrm{HGH}$ and NA helped in preparing final draft of manuscript, checked and corrected the grammar. All authors read and approved the final report.

\section{Conflict of interests}

All authors declare that no conflict of interest exist.

\section{Funding/Support \\ None}

\section{References}

1. ROME III. The functional gastrointestinal disorders. 3rd Ed. Virginia: Degnon Associates Inc. McLean; 2006.

2. Bray F, Ferlay J, Soerjomataram I, et al. Global cancer statistics 2018: GLOBOCAN estimates of incidence and mortality worldwide for 36 cancers in 185 countries. CA Cancer J Clin. 2018; 68: 394-424.

3. Rasquin A, Di Lorenzo C, Forbes D, Guiraldes E, Hyams JS, Staiano A, Walker LS. Childhood functional gastrointestinal disorders: child/adolescent. Gastroenterol. 2006; 130:15271537.

4. Korterink JJ, Diederen K, Benninga MA, Tabbers MM. Epidemiology of pediatric functional abdominal pain disorders: a meta-analysis. PLoS One. 2015; 10:e0126982.

5. Devanarayana NM, de Silva DG, de Silva HJ. Gastric myoelectrical and motor abnormalities in children and adolescents with functional recurrent abdominal pain. J Gastroenterol Hepatol. 2008; 23:1672-1677.

6. Devanarayana NM, Rajindrajith S, Bandara C, Shashiprabha G, Benninga MA. Ultrasonographic assessment of liquid gastric emptying and antral motility according to the subtypes of irritable bowel syndrome in children. J Pediatr Gastroenterol Nutr. 2013;56:443-448.

7. De M, Krishna De A, Banerjee A B. Antimicrobial screening of some Indian spices. Phytother Res. 1999; 13(7): 616-618.

8. Awtry EH, Loscalzo J. Aspirin. Circulation. 2000; 101:120618.

9. Jiang HP. Whelton PK. Aspirin and risk factor of hemorrhagic stroke. JAMA. 1998; 28(220):1930-35.

10. Kendall BJ. Peura DA. NSAIDs-associated gastrointestinal damage and the elderly. Pract Gasteroentrol. 1993; 17:13-29.

11. Alkofahi A, Atta HA. Pharmacological screening of anti-ulcerogenic effects of some Jordanian medicinal plants in rats. Ethnopharmacol. 1999; 67:341-5.

12. Dhuley JN. Protective effect of Rhinax: A herbal formulation against physical and chemical factors induced gastric and duodenal ulcers in rat. Ind J Pharmacol. 1999; 31:132128.

13. Abbasi N, Azizi Jalilian F, Abdi M, Saifmanesh M. A comparative study of the antimicrobial effect of Scrophularia striata Boiss. Extract and selective antibiotics against Staphylococcus aureus and Pesudomonas aeruginosa. J Medicinal Plants. 2007;6 (SUPPL. 1): 10-18.

14. Bahmani M, Khaksarian M, Rafieian-Kopaei M, Abbasi N. Overview of the therapeutic effects of Origanum vulgare and Hypericum perforatum based on Iran's ethnopharmacological documents. J Clini Diag Res. 2018; 12(7):1-4.

15. Shokri Z, Khoshbin M, Koohpayeh A, Abbasi N, Bahmani F, Rafieian-Kopaei, M, Beyranvand F. Thyroid diseases: Pathophysiology and new hopes in treatment with medicinal plants and natural antioxidants. International Journal of Green Pharmacy 2018;12(3):473-482.

16. Abbasi N, Mohammadpour S, Karimi E, Aidy A, Karimi P, Azizi M, Asadollahi K. Protective effects of Smyrnium cordifolium Boiss essential oil on pentylenetetrazol-induced 
seizures in mice: Involvement of benzodiazepine and opioid antagonists. J Biolog Regulators Homeostatic Agents. 2017; 31(3):683-689.

17. Tajbakhsh M, Karimi A, Tohidpour A, Abbasi N, Fallah F, Akhavan MM. The antimicrobial potential of a new derivative of cathelicidin from Bungarus fasciatus against methicillin-resistant Staphylococcus aureus. J Microbiol. 2018; 56(2):128-137. https://doi.org/10.1007/s12275-018-74445.

18. Bahmani M, Taherikalani M, Khaksarian M, Rafieian-Kopaei M, Ashrafi B, Nazer M, Soroush S, Abbasi N, Rashidipour M. The synergistic effect of hydroalcoholic extracts of Origanum vulgare, Hypericum perforatum and their active components carvacrol and hypericin against Staphylococcus aureus. Future Sci OA. 2019; 5(3): FSO371.

19. Chashti AKH. Great exsir. Institute for the Study of Medical History of Islamic Medicine and Supplement. Medical Uni Tehran. 2008; 386-41.

20. Ibn sina. Law in medicine. Institute of Islamic Studies. Volume 3, Lebanon, Beirut. 2005; 68-73.

21. Arzani MASH. Akbari medicine. First Edition. Natural Resurrection Institute, Qom. 2008; 539.

22. Almajousi AA. The whole natural industry, Volume 1, First Edition, Institute for the revival of natural medicine, Qum. 2006; 428.

23. Kermani NA. Explanation Causes Signs. Volume 1, First Edition, Institute for the revival of natural medicine, Qum. $2008 ; 601$.

24. Mozaffarian VA. Dictionary of Iranian Plant Names. Contemporary Culture Publishing House, Tehran, 1996.

25. Moemen-Tonekaboni SM. "Tohfatol moemenin". Correction and research: Rahimi R, Shams Ardakani MR, Farjadmand F, Publication of Medical Research Center, Tehran, Iran 1997; 637-663.

26. Jamshidi-Kia F, Lorigooini Z, Amini-Khoei H. Medicinal plants: past history and future perspective. J Herbmed Pharmacol. 2018;7(1):1-7. doi: 10.15171/jhp.2018.01

27. Memariani Z, Rahimi A, Farzaei MH, Zakaria Nejad N. Nepeta menthoides Boiss. \& Buhse, an endemic species in Iran: A review of traditional uses, phytochemistry and pharmacology. J Herbmed Pharmacol. 2019;8(3):194-204.

28. World Health Organisation. Health of indigenous peoples. Geneva, Switzerland: Factsheets N 326; 2007. http://www. who.int/mediacentre/factsheets/fs326/en/. Accessed 30 April 2015

29. Bahmani M, Zargaran A, Rafieian-Kopaei M. Identification of medicinal plants of Urmia for treatment of gastrointestinal disorders. Brazilian J Pharmacog. 2014; 24(4):468-80.

30. Nejad ASM, Bahmani M, Shah NA, Shah SA, Rafieian-Kopaei M. Beliefs of herbal therapies of the community of the Ilam city of Ilam province, Iran. J Pharmacy Pharmacog Res. 2018;6(4):299-317.

31. Sepahvand A, Ezatpour B, Tarkhan F, Bahmani M, Khonsari A, Rafieian-Kopaei M. Phytotherapy in fungi and fungal disease: a review of effective medicinal plants on important fungal strains and diseases. International J Pharmac Sci Res. 2017; 8(11):4473-95.

32. Talei GR, Mohammadi M, Bahmani M, Kopaei MR. Synergistic effect of Carum copticum and Mentha piperita essential oils with ciprofloxacin, vancomycin, and gentamicin on Gram-negative and Gram-positive bacteria. Intern J Pharmac Investig. 2017;7(2):82-7.
33. Rouhi-Boroujeni H, Heidarian E, Rouhi-Boroujeni H, Deris F, Rafieian-Kopaei M. Medicinal Plants with Multiple Effects on Cardiovascular Diseases: A Systematic Review. Current Pharmaceutical Design. 2017; 23(7):999-1015.

34. Nazarian-Samani Z, Sewell RDE, Lorigooini Z, Rafieian-Kopaei M. Medicinal plants with multiple effects on diabetes mellitus and its complications: a systematic review. Curr Diab Rep. 2018; 18: 72.

35. Askarinia M, Ganji A, Jadidi-Niaragh F, Hasanzadeh S, Bahram Mohammadi B, et al. A review on medicinal plant extracts and their active ingredients against methicillin-resistant and methicillin-sensitive Staphylococcus aureus. J Herbmed Pharmacol. 2019; 8(3):173-184. [36] Pourmirzaee Sheikhali Kelayeh T, Abedinzade M, Ghorbani A. A review on biological effects of Lamium album (white dead nettle) and its components. J Herbmed Pharmacol. 2019;8(3):185-193.

36. Bahmani M, Taherikalani M, Khaksarian M, Soroush S, Ashrafi B, Heydari R. Phytochemical profiles and antibacterial activities of Origanum vulgare and Hypericum perforatum and carvacrol and hypericin as a promising anti-Staphylococcus aureus. Mini Rev Med Chem. 2019. doi: 10.2174/1389557519666190121124317. [Epub ahead of print]

37. Umamahesh K, Ramesh B, Vijaya Kumar B, Reddy OVS. In vitro anti-oxidant, anti-microbial and anti-inflammatory activities of five Indian cultivars of mango (Mangifera indica L.) fruit peel extracts. J Herbmed Pharmacol. 2019; 8(3):238-247.

38. Karami S, Roayaei M, Zahedi E, Bahmani M, Mahmoodnia L, Hamzavi H, et al. Antifungal effects of Lactobacillus species isolated from local dairy products. International J Pharmac Investig. 2017; 7(2):77-81.

39. Essiet GA, Anwankwo MU, Akuodor GC, Ajoku GA, Ofor CC, Megwas AU, Aja DOJ. Antibacterial and toxicological evaluation of the ethanol leaf extract of Anthonotha macrophylla. J Herbmed Pharmacol. 2019; 8(3):205-211.

40. Kazemi S, Shirzad H, Rafieian-Kopaei M. Recent Findings in Molecular Basis of Inflammation and Anti-inflammatory Plants. Current Pharmaceutical Design. 2018;24(14):155162.

41. Shayganni E, Bahmani M, Asgary S, Rafieian-Kopaei M. Inflammaging and cardiovascular disease: Management by medicinal plants. Phytomed. 2016; 23(11):1119-26.

42. Ramezannezhad P, Nouri A, Heidarian E. Silymarin mitigates diclofenac-induced liver toxicity through inhibition of inflammation and oxidative stress in male rats. $\mathrm{J}$ Herbmed Pharmacol. 2019;8(3):231-237.

43. Kravchenko I, Eberle L, Nesterkina M, Kobernik A. Anti-inflammatory and analgesic activity of ointment based on dense ginger extract (Zingiber officinale). J Herbmed Pharmacol. 2019;8(2):126-132.

44. Saryono S, Taufik A, Proverawati A, Efendi F. Dietary supplementation of Phoenix dactylifera L. seeds decreases pro-inflammatory mediators in $\mathrm{CCl} 4$-induced rats. J Herbmed Pharmacol. 2019; 8(3):212-217.

45. Hidekazu S, Hidekazu S, Toshihiro N, Hitoshi T. Roles of oxidative stress in stomach disorders. J Clin Biochem Nutr. 2012; 50(1):35-9. DOI: 10.3164/jcbn.11-115SR.

46. González-Trujano ME, Pellicer F, Mena P, Moreno DA, García-Viguera C. Antinociceptive and anti-inflammatory activities of a pomegranate (Punica granatum L.) extract 
rich in ellagitannins. Int J Food Sci Nutr. 2015; 66(4):395-9.

47. Ortiz MI, Fernández-Martínez E, Soria-Jasso LE, Lucas-Gómez I, Villagómez-Ibarra R, González-García MP, Castañeda-Hernández G, Salinas-Caballero M. Isolation, identification and molecular docking as cyclooxygenase (COX) inhibitors of the main constituents of Matricaria chamomilla L. extract and its synergistic interaction with diclofenac on nociception and gastric damage in rats. Biomed Pharmacother. 2016; 78: 248-256.

48. F.UAfifi, EKhalil, S.OTamimi, ADisi. Evaluation of the gastroprotective effect of Laurus nobilis seeds on ethanol induced gastric ulcer in rats. J Ethnopharmacol. 1997; 58, (1): 9-14.

49. Robert J.Shulman, Emily B.Hollister, KevinCain, Danita I.Czyzewski, Mariella M.Self, Erica M.Weidler, SrideviDevaraj. Psyllium Fiber Reduces Abdominal Pain in Children With Irritable Bowel Syndrome in a Randomized, Double-Blind Trial. Clinical Gastroenterol Hepatol. 2017; 5(5: 712-719.e4.

50. Kaithwas, Gaurav, Mukherjee, Alok, Chaurasia, A K, Majumdar, Dipak K. Antiinflammatory, analgesic and antipyretic activities of Linum usitatissimum L. (flaxseed/linseed) fixed oil. IJEB. 2011; 49(12): 932-938.

51. Anand M.Ingale, Venkata BharatKumar Pinnelli2, VijayaRajendran. Experimental evaluation of the anti-ulcer activity of the ethanolic extract of grape (Vitis vinifera) seed in wistar albino rats against aspirin plus pylorus ligation induced gastric ulcer model. Intern J Basic \& Clin Pharmacol. 2016; 7(3): 722-727.

52. Mohammad-Ali Kiani, Ahmad Khodadad, Shabnam Mohammadi, Majid Ghayour Mobarhan, Masumeh Saeidi, Seyed Ali Jafari, Ebrahim Kiani, Hamid Ahanchian. Effect of peppermint on pediatrics' pain under endoscopic examination of the large bowel. J HerbMed Pharmacol. 2013; 2(2): 41-44.

53. Sajeli Begum, Bhagawati Saxena, Madhur Goyal, Rakesh Ranjan, Vijaya B.Joshi et al., Study of anti-inflammatory, analgesic and antipyretic activities of seeds of Hyoscyamus niger and isolation of a new coumarinolignan. Fitoterapia. 2010; 81(3): 178-184.

54. KChan, M.WIslam, MKamil, RRadhakrishnan, M.N.MZakaria, MHabibullah, AAttas. The analgesic and anti-inflammatory effects of Portulaca oleracea L. subsp. sativa (Haw.) Celak. J Ethnopharmacol. 2000; 73(3): 445-451.

55. Sangeeta P Bhat, WaseemRizvi, Anil Kuma. Coriandrum sativum on pain and inflamatory. IJRPC. 2014; 4(4): 939-945.

56. Raji Y, Udoh US, Oluwadara OO, Akinsomisoye OS, Awobajo O, Adeshoga K. Anti-inflamatory and analgesic properties of the rhizome extract of Zingiber officinalis. Afr. J. Biomed. Res. 2002; 5:121-124.

57. Mallika Jainu \& C. S. Shyamala Devi. Antioxidant effect of methanolic extract ofSolanum nigrum berries on aspirin induced gastric mucosal injury. Indian J Clin Biochem.2004; 19: $57-61$.

58. Khalid S, Shaik Mossadeq W.M, Israf D.A, Hashim P, Rejab S, Shaberi A.M, Mohamad A.S, Zakaria Z.A, Sulaiman M.R. In vivo Analgesic Effect of Aqueous Extract of Tamarindus indica L. Fruits. Med Princ Pract .2010; 19: 255-259.

59. Karimi A, Mohammadi-Kamalabadi M, Rafieian-Kopaei M, Amjad L, Salimzadeh I. Determination of antioxidant activity, phenolic contents and antiviral potential of metha- nol extract of Euphorbia spinidens Bornm (Euphorbiaceae). Tropical J Pharmac Res. 2016; 15(4):759-64.

60. Feghhi-Najafabadi S, Safaeian L, Zolfaghari B. In vitro antioxidant effects of different extracts obtained from the leaves and seeds of Allium ampeloprasum subsp. persicum. J Herbmed Pharmacol. 2019; 8(3):256-260. 